Article

\title{
Numerical Investigation on the Intraphase and Interphase Mass Transfer Limitations for $\mathrm{NH}_{3}-\mathrm{SCR}$ over $\mathrm{Cu}-\mathrm{ZSM}-5$
}

\author{
Shiyong $\mathrm{Yu}^{1}$ and Jichao Zhang ${ }^{1,2, *}$ \\ 1 School of Marine Engineering, Jiangsu Shipping College, Nantong 226010, China; ysy@jssc.edu.cn \\ 2 Merchant Marine College, Shanghai Maritime University, Shanghai 201306, China \\ * Correspondence: zjc@jssc.edu.cn
}

Citation: Yu, S.; Zhang, J. Numerical Investigation on the Intraphase and Interphase Mass Transfer Limitations for $\mathrm{NH}_{3}$-SCR over Cu-ZSM-5.

Processes 2021, 9, 1966. https:// doi.org/10.3390/pr9111966

Academic Editor: Jiaqiang E

Received: 26 September 2021

Accepted: 30 October 2021

Published: 4 November 2021

Publisher's Note: MDPI stays neutral with regard to jurisdictional claims in published maps and institutional affiliations.

Copyright: (C) 2021 by the authors Licensee MDPI, Basel, Switzerland. This article is an open access article distributed under the terms and conditions of the Creative Commons Attribution (CC BY) license (https:// creativecommons.org/licenses/by/ $4.0 /$ )

\begin{abstract}
A systematic modeling approach was scrutinized to develop a kinetic model and a novel monolith channel geometry was designed for $\mathrm{NH}_{3}$ selective catalytic reduction $\left(\mathrm{NH}_{3}-\mathrm{SCR}\right)$ over $\mathrm{Cu}-$ ZSM-5. The redox characteristic of $\mathrm{Cu}$-based catalysts and the variations of $\mathrm{NH}_{3}, \mathrm{NO}_{\mathrm{x}}$ concentration, and $\mathrm{NO}_{\mathrm{x}}$ conversion along the axis in porous media channels were studied. The relative pressure drop in different channels, the variations of $\mathrm{NH}_{3}$ and $\mathrm{NO}_{x}$ conversion efficiency were analyzed. The model mainly considers $\mathrm{NH}_{3}$ adsorption and desorption, $\mathrm{NH}_{3}$ oxidation, $\mathrm{NO}$ oxidation, and $\mathrm{NO}_{\mathrm{x}}$ reduction. The results showed that the model could accurately predict the $\mathrm{NH}_{3}$-SCR reaction. In addition, it was found that the $\mathrm{Cu}$-based zeolite catalyst had poor low-temperature catalytic performance and good high-temperature activity. Moreover, the catalytic reaction of $\mathrm{NH}_{3}-\mathrm{SCR}$ was mainly concentrated in the upper part of the reactor. In addition, the hexagonal channel could effectively improve the diffusion rate of gas reactants to the catalyst wall, reduce the pressure drop and improve the catalytic conversion efficiencies of $\mathrm{NH}_{3}$ and $\mathrm{NO}_{\mathrm{x}}$.
\end{abstract}

Keywords: $\mathrm{NH}_{3}-\mathrm{SCR}$; diesel engine; $\mathrm{Cu}-\mathrm{ZSM}-5$; $\mathrm{NO}_{x}$ conversion efficiency

\section{Introduction}

A diesel engine is widely used in ships and automobiles [1] because of its high thermal efficiency [2], low fuel consumption [3], low emission, and high efficiency [4]. However, the nitrogen oxides $\left(\mathrm{NO}_{\mathrm{x}}\right)$ and particulate matter $(\mathrm{PM})$ emitted by diesel engines pose a significant threat to human health and the environment [5]. PM is produced by incomplete combustion at low temperature [6], while $\mathrm{NO}_{\mathrm{x}}$ is produced by combustion at high temperature and oxygen enrichment [7]. The $\mathrm{NO}_{\mathrm{x}}$ limits for Euro $\mathrm{V}$ and Euro VI are $0.18 \mathrm{~g} / \mathrm{km}$ and $0.08 \mathrm{~g} / \mathrm{km}$, respectively [8]. In order to meet this lower limit, when $\mathrm{NO}_{\mathrm{x}}$ emission exceeds $0.08 \mathrm{~g} / \mathrm{km}$, heavy vehicles need to be equipped with aftertreatment devices, such as selective catalytic reduction (SCR) and Lean $\mathrm{NO}_{\mathrm{x}}$ Trap (LNT). Nowadays, the world environment is becoming worse and worse. The governments and organizations have formulated relevant emission limitation regulations, which are becoming increasingly stringent [9]. At the same time, the International Maritime Organization (IMO) also developed the marine diesel engine MAPPOL 73/78 anti-pollution convention in the bylaw VI of the marine diesel engine $\mathrm{NO}_{\mathrm{x}}$ emissions to make a strict limit, the by-law and in January 2000 came into force [10]. The 2019 Annual Report on Motor Vehicle Pollution Prevention and Control in China showed that diesel vehicles accounted for a large share of pollution in 2018, with $\mathrm{NO}_{x}$ emissions accounting for $70 \%$ of total emissions. Facing the problem of global environmental degradation, how to effectively reduce diesel engine emissions has become the main task of sustainable development of human society [11].

Reducing $\mathrm{NO}_{\mathrm{x}}$ and particulate emissions has become the focus [12]. The SCR has been widely promoted in recent years due to its good technical economy, high reliability, and insensitive to sulfur [13]. However, in the stage of National IV and above emission regulations, $\mathrm{NH}_{3}$-SCR is one of the most commonly used aftertreatment technologies for reducing $\mathrm{NO}_{x}$ emission of heavy-duty diesel engine [14]. This technology generates 
ammonia through chemical reactions such as pyrolysis and hydrolysis of urea. Ammonia is adsorbed and stored on the catalyst surface and then reacts with $\mathrm{NO}_{\mathrm{x}}$ in exhaust gas to generate nitrogen $\left(\mathrm{N}_{2}\right)$ and water $\left(\mathrm{H}_{2} \mathrm{O}\right)$ to reduce $\mathrm{NO}_{x}$ emission [15]. In recent years, the molecular zeolite catalysts have been widely used to study the reduction of NO in $\mathrm{NH}_{3}$-SCR system [16] because of their unique microporous structure, rich acid sites, and strong thermal stability [17]. ZSM-5 molecular zeolite has a unique three-dimensional pore structure, large specific surface area, and strong $\mathrm{NO}_{\mathrm{x}}$ adsorption capacity. It shows excellent catalytic performance in $\mathrm{NO}_{x}$ emission control of diesel engines and automobile exhaust [18]. However, the selective catalytic reduction activity of a single molecular zeolite is poor, which cannot meet the requirements of vehicle SCR technology.

At present, many experts and scholars unanimously seek better methods to improve SCR technology, especially in SCR catalyst, catalyst surface reaction mechanism, urea atomization, aftertreatment device design, and catalyst preparation. However, it is difficult to replace SCR catalyst in engine bench or vehicle test, the test conditions are poor and the extensive human and material resources invested. Therefore, the study of small catalyst samples in the SCR simulation reaction system can accurately control the reaction parameters of SCR catalytic reaction, such as temperature, space velocity, ammonia nitrogen ratio, and can conduct a more targeted and detailed study on the performance of the catalyst. Therefore, the most $\mathrm{NH}_{3}$-SCR uses zeolite molecular zeolite and transition metal groups (such as V [19], $\mathrm{Cu}$ [20], Fe [21] and Mn [22]) as catalysts for the reaction [23]. The vanadiumbased catalyst is an early commercial $\mathrm{deNO}_{x}$ catalyst with the advantages of high activity, high selectivity, and good sulfur resistance [24]. However, it has a narrow working window $\left(350-450{ }^{\circ} \mathrm{C}\right)$, poor low-temperature activity, and poor high-temperature stability [25]. The $\mathrm{Cu}$-exchanged zeolites are active both in the reduction of nitrogen oxides with $\mathrm{NH}_{3}$ in SCR system and in the direct decomposition of NO. In addition, Cu-exchanged zeolites SCR reactor includes a lot of parallel channels and mostly uses cordierite as substrate for its low cost, high thermal stability, and superior mechanical strength. Due to a relatively wide operating temperature range and the great low-temperature ignition characteristic, $\mathrm{Cu}$ zeolites are widely used in experimental research and application due to the high catalytic performance under normal vehicle exhaust temperatures. The heterogeneity of the reactive sites and numerous potential metal oxidation states that are prepared by incorporation of metal atoms into the zeolite framework result in complex zeolite catalysts. It can be found that $\mathrm{Cu}$-zeolites active sites are various forms of copper oxides, $\mathrm{Cu}^{2+}$ and $\mathrm{Cu}^{+}$, or inherent Bronsted acid sites that present in the pores of the zeolites [26]. In 1986, Iwamoto et al. [27] found that the activity of Cu-ZSM- 5 catalyst formed by exchanging $\mathrm{Cu}$ ions into ZSM-5 molecular sieve is much higher than that formed by exchanging $\mathrm{Cu}$ ions into other types of molecular sieves. In the following decades, researchers have carried out much research on catalytic decomposition by Cu-ZSM-5 [28].

Many experimental and numerical studies had been carried out on SCR coated with $\mathrm{Cu}$-zeolites. For example, Na et al. [29] derived a nonlinear model based on the physical and chemical interpretation of the catalyst and some simplifications. Then, they discretized and linearized the nonlinear equations and analyzed the system dynamics of the catalyst. Through control, the maximum $\mathrm{NO}_{x}$ conversion could be achieved with minimum $\mathrm{NH}_{3}$ leakage, and the model's performance was verified by the SCR simulation reaction system. Zhong et al. [30] established a single channel $\mathrm{NH}_{3}-\mathrm{SCR}$ model of SCR system with Cu-ZSM-5 as a catalyst to study the mass and heat transfer processes between gas and solid phases. It was found that the deNO $\mathrm{N}_{x}$ efficiency was mainly influenced by intra-phase diffusion at $200-500{ }^{\circ} \mathrm{C}$, while it was mainly influenced by inter-phase mass transfer at medium and high temperatures. Colombo et al. [31] experimentally studied the reaction law of $\mathrm{Cu}$-based molecular zeolite $\mathrm{NH}_{3}$-SCR and analyzed the conversion of $\mathrm{NO}_{\mathrm{x}}$ in detail. Auvray et al. [32] established an axial spatial kinetic model of $\mathrm{Cu}$-based molecular zeolite $\mathrm{NH}_{3}$-SCR reaction and analyzed the influence of $\mathrm{NH}_{3}-\mathrm{SCR}$ catalytic reaction. They found that pore diffusivity had little effect on it. In addition, Henry et al. [33] studied the axial spatial distribution of $\mathrm{Cu}$-based molecular Auvray et al. [32] and established an axial 
spatial kinetic model of $\mathrm{Cu}$-based molecular zeolite $\mathrm{NH}_{3}-\mathrm{SCR}$ reaction and analyzed the influence of $\mathrm{NH}_{3}-\mathrm{SCR}$ catalytic reaction. They analyzed the fast and standard SCR reaction conversion at each length position in the axial direction. Many accurate and effective experiment data can be obtained by simulating the engine test bench and evaluating catalyst performance by an SCR simulation reaction system. Compared with the engine bench test, it can eliminate the interference of the external environment and is more conducive to the systematic and scientific study of the reaction kinetic model of the catalyst.

Based on above, it is of great significance to study the influence of the Cu-ZSM-5 catalyst reaction kinetic model on the SCR system. Thus, a 3D- computational fluid dynamics model is established and employed to investigate the reaction kinetic model of $\mathrm{Cu}$ molecular sieve catalytic. In addition, the relative pressure drop, $\mathrm{NH}_{3}$ conversion, and $\mathrm{NO}_{x}$ conversion efficiency in different channels were analyzed to provide some reference for improving, optimizing, and applying the $\mathrm{NH}_{3}-\mathrm{SCR}$ system. Thus, the work is very interesting.

\section{Methods and Model Validation}

\subsection{SCR Reaction Kinetic Model}

The SCR catalytic reactor has many parallel small-sized channels, a large channel length-width ratio, and a large number of channels. In the process of calculation, it is assumed that the flow field of the inlet gas of the SCR reactor is evenly distributed, and the heat transfer loss of the system to the environment is ignored. As shown in Figure 1, the phenomena of SCR mainly involves axial convection and diffusive transport in the gas phase, mass transfer through the gas-solid interface, and radial diffusion and catalytic reactions on the coating. When the $\mathrm{NH}_{3}, \mathrm{NO}_{\mathrm{x}}$, and $\mathrm{O}_{2}$ in the channel enter the coating (interphase transfer), $\mathrm{NH}_{3}$ is adsorbed on the catalyst's active sites and subsequently reacts with $\mathrm{NO}_{\mathrm{x}}$ and $\mathrm{O}_{2}$ for reduction. The remaining $\mathrm{NH}_{3}, \mathrm{NO}_{\mathrm{x}}$, and $\mathrm{O}_{2}$ enter the coating (in-phase mass transfer) and continue to react with each other. At the same time, the generated $\mathrm{H}_{2} \mathrm{O}, \mathrm{N}_{2}$, and other substances finally diffuse into the channels through the gaps. In the process of establishing the model, the mass transfer at the gas-solid interface adopts Cauchy boundary conditions, and the Hawthorn [34] equation calculates its mass transfer coefficient. At the same time, the model makes the following assumptions:

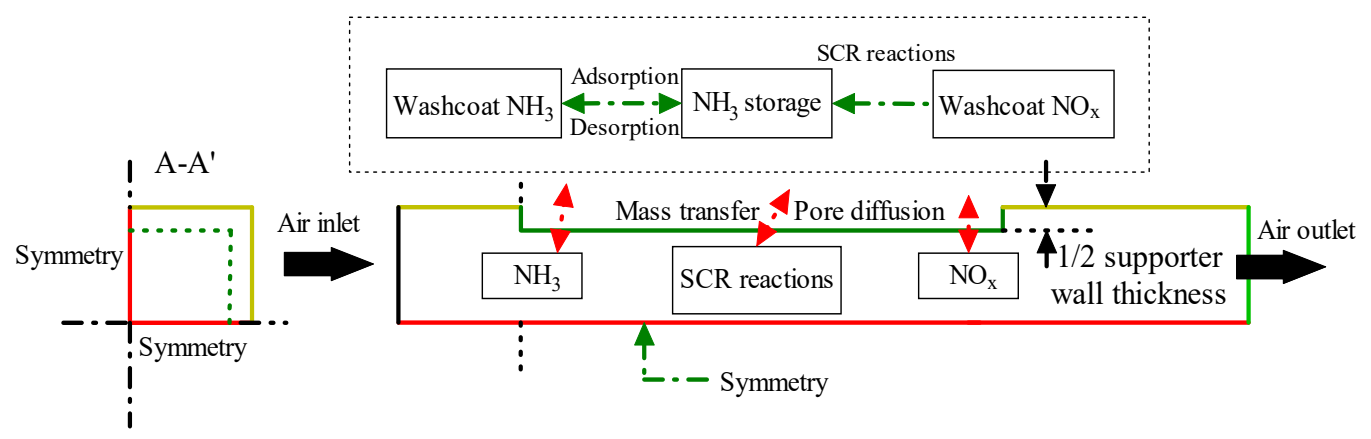

Figure 1. Schematic diagram of single-channel in selective catalytic reduction (SCR).

1. Ignore the diffusion between the whole channel, the hydrolysis of isocyanate and urea. $\mathrm{NH}_{3}$ directly enters the channel.

2. Assuming that the inlet boundary condition of the channel is uniform, the Eley-Rideal mechanism is used to calculate the surface catalytic reaction of the $\mathrm{Cu}$ molecular sieve.

3. The active catalyst is evenly coated on the coating surface, and the porous medium of the coating is evenly distributed. 
The continuity equation, momentum equation, and enthalpy balance equation of gas-phase components in the channel can be expressed as follows [30]:

$$
\begin{gathered}
\frac{\partial\left(\rho y_{i}\right)}{\partial t}+\frac{\partial\left(\rho v y_{i}\right)}{\partial z}=D_{i} \frac{\partial^{2} \rho y_{i}}{\partial z^{2}} \\
\frac{\partial(\rho v)}{\partial t}+\frac{\partial\left(\rho v^{2}\right)}{\partial z}=\mu \frac{\partial^{2} v}{\partial z^{2}}-\frac{\partial p}{\partial z} \\
c_{p} \frac{\partial\left(\rho T_{g}\right)}{\partial t}+c_{p} \frac{\partial\left(\rho v T_{g}\right)}{\partial z}=\lambda_{g} \frac{\partial^{2} T_{g}}{\partial z^{2}}
\end{gathered}
$$

where $\rho$ is the fluid density, $\mathrm{kg} / \mathrm{m}^{3} ; y$ is the mass fraction of component, $\% ; v$ is the volume, $\mathrm{m}^{3} ; t$ is time, $\mathrm{s} ; z$ is the axial distance, $\mathrm{m} ; D_{i}$ is the diffusion coefficient of the species $i$ in pores, $\mathrm{m}^{2} / \mathrm{s} ; \mu$ is the viscosity, Pa.s; $c_{p}$ is the specific heat capacity, $\mathrm{J} /(\mathrm{kg} \cdot \mathrm{K}) ; T$ is the temperature, $\mathrm{K}$; and $\lambda$ is the thermal conductivity, $\mathrm{W} /(\mathrm{m} \cdot \mathrm{K})$.

The composition continuity equation, enthalpy balance equation, and $\mathrm{NH}_{3}$ coverage balance equation of gaseous substances in the coating are as follows [30]:

$$
\begin{gathered}
D_{w, i} \frac{\partial \rho_{w} y_{w, i}}{\partial x^{2}}-a_{c} M_{i} \sum_{j} \gamma_{i, j} r_{j}=\frac{\partial\left(\rho_{w} y_{w, i}\right)}{\partial t} \\
a_{c} \sum_{j} \Delta H_{m, j} r_{j}(T)+\lambda_{w} \frac{\partial^{2} T_{w}}{\partial x^{2}}=c_{p} \frac{\partial\left(\rho_{w} T_{w}\right)}{\partial t} \\
\Omega \frac{\partial \theta_{N H_{3}}}{\partial t}=\sum_{j=1}^{J} \gamma_{N H_{3, j}} r_{j}
\end{gathered}
$$

where $D_{w, i}$ is the effective diffusion coefficient of component $i, \mathrm{~m}^{2} / \mathrm{s} ; x$ is the mole fraction of component, \%; $\mathrm{y}_{w, i}$ is the mass fraction of component $i, \% ; a_{c}$ is the geometric surface area $\mathrm{m}^{2} / \mathrm{m}^{3} ; M_{i}$ is the molar mass of each $i$ component, $\mathrm{g} / \mathrm{mol} ; r_{j}$ is the reaction rate of reaction $j, \mathrm{~mol} /\left(\mathrm{s} \cdot \mathrm{m}^{3}\right) ; \Delta H_{m, j}$ is the enthalpy of reaction $j, \mathrm{~J} / \mathrm{mol} ; \Omega$ is $\mathrm{NH}_{3}$ storage capacity, $\mathrm{mol} / \mathrm{m}^{3} ; \theta_{\mathrm{NH} 3}$ is the $\mathrm{NH}_{3}$ surface site fraction; and $\gamma_{i, j}$ is the stoichiometric coefficient of the reaction of component $i$ at $j$.

The component continuity equation and enthalpy balance equation between gas and coating are as follows [30]:

$$
\begin{gathered}
\left.D_{w, k} \frac{\partial y_{w, k}}{\partial x}\right|_{x= \pm \frac{d_{h}}{2}}=k_{m}\left(y_{b, k}-y_{w, k}\right) \\
\left.\lambda_{w} \frac{\partial T_{w}}{\partial x}\right|_{x= \pm \frac{d_{h}}{2}}=h_{T} a_{\mathcal{c}}\left(T_{g}-T_{w}\right)
\end{gathered}
$$

where $k_{m}$ is the mass transfer coefficient, $\mathrm{kg} /\left(\mathrm{m}^{2} \cdot \mathrm{s}\right) ; h_{T}$ is the heat transfer coefficient, $\mathrm{kg} /\left(\mathrm{s} \cdot \mathrm{m}^{2}\right) ; d_{h}$ is the channel length, $\mathrm{m}$; and $k$ is the reaction constant, $\mathrm{s}^{-1}$.

The main reactions of the $\mathrm{NH}_{3}-\mathrm{SCR}$ catalytic reduction reaction are shown in Table 1.

Table 1. Catalytic reaction of $\mathrm{Cu}$ molecular sieve.

\begin{tabular}{cc}
\hline NO. & Reactions \\
\hline R1 & $N_{3}+S_{1} \rightarrow \mathrm{NH}_{3}-\mathrm{S}_{1}$ \\
$\mathrm{R} 2$ & $\mathrm{NH}_{3}-\mathrm{S}_{1} \rightarrow \mathrm{NH}_{3}+\mathrm{S}_{1}$ \\
$\mathrm{R} 3$ & $2 \mathrm{NO}-\mathrm{O}_{2} \rightleftarrows 2 \mathrm{NO}_{2}$ \\
$\mathrm{R} 4$ & $2 \mathrm{NH}_{3}-\mathrm{S}_{1}+\mathrm{NO}_{2}+\mathrm{NO} \rightarrow 2 \mathrm{~N}_{2}+3 \mathrm{H}_{2} \mathrm{O}+2 \mathrm{~S}_{1}$ \\
$\mathrm{R} 5$ & $4 \mathrm{NH}_{3}-\mathrm{S}_{1}+4 \mathrm{NO}_{2}+\mathrm{O}_{2} \rightarrow 4 \mathrm{~N}_{2}+6 \mathrm{H}_{2} \mathrm{O}+4 \mathrm{~S}_{1}$ \\
$\mathrm{R} 6$ & $4 \mathrm{NH}_{3}-\mathrm{S}_{1}+3 \mathrm{O}_{2} \rightarrow 2 \mathrm{~N}_{2}+6 \mathrm{H}_{2} \mathrm{O}+4 \mathrm{~S}_{1}$ \\
\hline
\end{tabular}


In addition, the $\mathrm{NH}_{3}$ desorption activation energy parameter is modified by Temkin, and the following equation can calculate the $\mathrm{NH}_{3}$ adsorption and desorption reaction rates:

$$
\begin{gathered}
r_{a d s}=k_{a d s} c_{\mathrm{NH}_{3}}\left(\theta_{\text {max. } \mathrm{NH}_{3}}-\theta_{\mathrm{NH}_{3}}\right) \\
r_{\text {des }}=k_{\text {des }} \theta_{\mathrm{NH}_{3}}
\end{gathered}
$$

where $r_{\text {des }}$ and $r_{a d s}$ is the reaction rates of $\mathrm{NH}_{3}$ desorption and adsorption, $\mathrm{mol} /\left(\mathrm{s} \cdot \mathrm{m}^{3}\right)$; $k_{d e s}$ and $k_{a d s}$ is the reaction rate constant of $\mathrm{NH}_{3}$ desorption and adsorption, $\mathrm{s}^{-1} ; c_{\mathrm{NH}}$ is the $\mathrm{NH}_{3}$ molar concentration, $\mathrm{mol} / \mathrm{m}^{3}$.

The $\mathrm{NO}$ and $\mathrm{NH}_{3}$ reaction rates can be obtained by the following equation:

$$
\begin{gathered}
r_{\mathrm{NH}_{3}}=k_{\mathrm{NH}_{3} c_{\mathrm{O}_{2}}} \theta_{\mathrm{NH}_{3}} \\
r_{\mathrm{NO}}=k_{\mathrm{NO}}\left(\mathrm{C}_{\mathrm{NO}}^{1 / 2} c_{o_{2}}-c_{\mathrm{NO}} / k_{e q}\right)
\end{gathered}
$$

where $r_{\mathrm{NH} 3}$ and $r_{\mathrm{NO}}$ is the reaction rates of $\mathrm{NH}_{3}$ and $\mathrm{NO}, \mathrm{mol} /\left(\mathrm{s} \cdot \mathrm{m}^{3}\right) ; k_{e q}, k_{\mathrm{NH} 3}$ and $k_{\mathrm{NO}}$ is the reaction rate constants of equilibrium, $\mathrm{NH}_{3}$ and $\mathrm{NO}, \mathrm{s}^{-1} ; c_{\mathrm{NO}}$ and $c_{\mathrm{O} 2}$ is the $\mathrm{NO}$ and $\mathrm{O}_{2}$ molar concentration, $\mathrm{mol} / \mathrm{m}^{3}$.

The rapid and stand reaction rates can be obtained by the following equation:

$$
\begin{gathered}
r_{\text {rap }}=k_{\text {rap }} c_{\mathrm{NO}_{\mathrm{O}} c_{2}} \theta_{\mathrm{NH}} \theta_{3}\left[1-\exp \left(-\theta_{\mathrm{NH}_{3}} / \theta_{\mathrm{NH}_{3}}^{*}\right)\right] \\
r_{s t a}=k_{s t a} c_{\mathrm{NO}} \theta_{\mathrm{NH}_{3}}^{*}\left[1-\exp \left(-\theta_{\mathrm{NH}_{3}} / \theta_{\mathrm{NH}_{3}}^{*}\right)\right]
\end{gathered}
$$

where $r_{\text {rap }}$ and $r_{\text {sta }}$ is the rapid and stand reaction rates, $\mathrm{mol} /\left(\mathrm{s} \cdot \mathrm{m}^{3}\right) ; k_{r a p}$ and $k_{\text {sta }}$ is the rapid and stand reaction rate constants, $\mathrm{s}^{-1} ; c_{\mathrm{NO} 2}$ is the $\mathrm{NO}_{2}$ molar concentration, $\mathrm{mol} / \mathrm{m}^{3}$, $\theta^{*}{ }_{N H 3}$ is the critical $\mathrm{NH}_{3}$ surface concentration value.

\subsection{Pore Diffusion Model}

Diffusion phenomena in pore media are widely present in external mass transfer and internal mass transfer processes in porous media. The diffusion of components in the diesel exhaust gas in SCR porous media is related to the micropores' pore size, length, and shape [35]. The multi-component diffusion coefficient is obtained by the following equation:

$$
D_{i m}^{\text {bulk }}=\frac{1-x_{i}}{\sum_{j=1}^{N} j \neq i \frac{x_{j}}{D_{i j}}}
$$

The molecular diffusion coefficient of binary bulk can be obtained by the following equation [35]:

$$
D_{i j}^{\text {bulk }}=\frac{3.198 \times 10^{-8} T^{1.75}}{P\left(V_{i}^{1 / 3}+V_{j}^{1 / 3}\right)}\left(\frac{1}{M_{i}}+\frac{1}{M_{j}}\right)^{0.5}
$$

The Knudsen diffusion coefficient can be obtained by the following equation [36]:

$$
D_{k}=48.5 d_{p} \sqrt{\frac{T}{M}}
$$

The tortuosity square or tortuosity factor enters into the final form of the effective coefficient. In addition, the increase of superficial flux and the additional path length are considered. Based on the residence time of component $i$ in the porous structure, a relation between the effective and pore gas diffusion coefficients is obtained by the following equation [37]:

$$
D_{i}^{e f f}=\frac{\varepsilon D_{i, b u l k}}{\left(l_{e} / l\right)^{2}}=\frac{\varepsilon}{\tau^{2}} D_{i, b u l k}
$$


where $\tau$ is the tortuosity factor; $l$ is the actual length of coating hole, $\mathrm{m} ; l_{e}$ is the total length of coating, $\mathrm{m}$; $\varepsilon$ is the porosity of washcoat.

Based on the stationary and not-stationary diffusion, the Equation (18) is also confirmed in Ref. [38]. The porous structure is showed in Figure 2. The porous structure includes many cylindrical pores with the same cross-sectional area $S_{\perp}$. The length of each pore can be obtained by the following equation [39].

$$
l_{e}=\int d l_{e}=\int \frac{d l}{\cos \theta}
$$

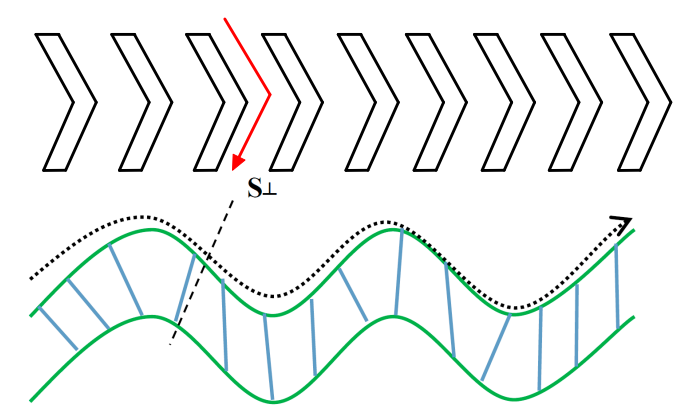

$\mathrm{d} l_{e}$

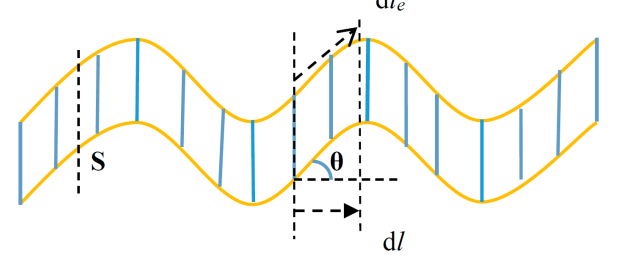

Figure 2. Simplified coating model.

The above equation is reduce to $l_{e}=l / \cos \theta$. If there are $n$ such pores per unit surface of the porous material, the porosity $\varepsilon$ is obtained by the equation [30]:

$$
\varepsilon=n S_{\perp} \frac{l_{e}}{l}
$$

where $S_{\perp}$ is cross-sectional area, $\mathrm{m}^{2}$.

Therefore, the total macroscopic molar diffusion flux in porous media in the sinusoidal capillary model can be calculated by the following equation [38]:

$$
\sum N=n S_{\perp} D^{b u l k} \frac{\triangle c}{l_{e}}=\varepsilon \frac{D^{b u l k}}{\left(l_{e} / l\right)^{2}} \frac{\triangle c}{l}=D^{e f f} \frac{\triangle c}{l}
$$

where $D^{\text {bulk }}$ is the bulk molecular diffusion coefficient; the $\Delta c$ is the concentration difference of $i$ component; the equation gives $D^{e f f}=\varepsilon \frac{D^{b u l k}}{\left(l_{e} / l\right)^{2}}$, where $\tau=\left(l_{e} / l\right)^{2}$ is the tortuosity factor.

The tortuosity square can be employed to estimate the gas diffusion coefficients. A sudden change of any species concentration is put on the left-hand side in Figure 2, and the concentration on the right-hand side will start to increase after a certain time. The time can be obtained by the following equation [39]:

$$
t=\left(l_{e}\right)^{2} / D^{b u l k} \approx l^{2} / D^{e f f}
$$

According to the characteristics of the research object, the diffusion coefficients in the mesopores $D_{i m}^{e f f}$ is a combination of the bulk and Knudsen diffusivities. Thus, the 
multi-component effective gas diffusion coefficient can be calculated by the following equation [38]:

$$
D_{i m}^{e f f}=\varepsilon^{2}\left(\frac{1}{D_{i m}^{b u l k}}+\frac{1}{D_{k}}\right)^{-1}
$$

where $D_{\text {im }}{ }^{\text {bulk }}$ is the diffusion coefficient of multi-component in the channel, $\mathrm{m}^{2} / \mathrm{s} ; D_{k}$ is Knudsen diffusion coefficient, $\mathrm{m}^{2} / \mathrm{s} ; D_{i m}{ }^{e f f}$ is the effective diffusion coefficient of multicomponent, $\mathrm{m}^{2} / \mathrm{s}$.

According to the conclusions and practical application of Ref. [40], the porosity value selects $\varepsilon=\tau^{-2 / 3}$ [41]. The calculated effective diffusion coefficients of reaction products $\mathrm{O}_{2}$, $\mathrm{NO}$ and $\mathrm{NH}_{3}$ are shown in Figure 3. It can be found that the model can accurately calculate the effective diffusion coefficient of each component.

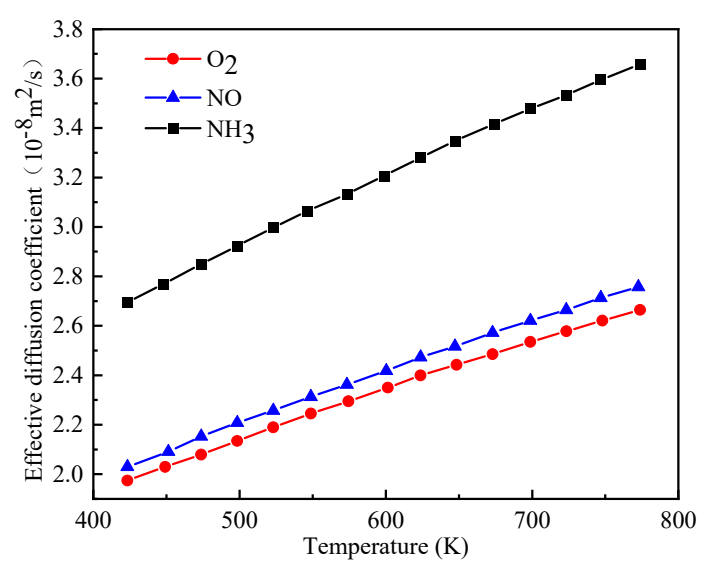

Figure 3. Effective diffusion coefficients of $\mathrm{O}_{2}, \mathrm{NO}$, and $\mathrm{NH}_{3}$, in the coating.

\subsection{Model Validation}

In order to verify the accuracy of the simulation model, the Cu-ZSM-5 molecular sieves catalytic reactor was used to verify the model. The main parameters of the $\mathrm{Cu}$-based molecular sieve catalytic reactor and catalyst are shown in Table 2. The AVL AMAi60 gas analyzer was used for the measurement. The different temperatures, flows, and pressures were measured by the corresponding sensors. The specific test bench is shown in Figure 4. The bench can generate The $\mathrm{NH}_{3}$ of $500 \times 10^{-6}$, NO of $500 \times 10^{-6}, 2 \% \mathrm{H}_{2} \mathrm{O}$ and $5 \% \mathrm{O}_{2}$ $\left(\mathrm{GHSV}=7200 \mathrm{~h}^{-1}\right)$ can be generated by the experimental bench and the intake air can be controlled by the adjust valve. Then the gas is heated by a heater, and finally, a catalytic reaction occurs in the SCR catalyst. In order to prevent the cross-contamination of catalysts, all catalysts were first run with $5 \% \mathrm{O}_{2}$ and $\mathrm{N}_{2}$ for $20 \mathrm{~min}$ at $500{ }^{\circ} \mathrm{C}$ to completely remove residual $\mathrm{NO}_{x}$ and $\mathrm{NH}_{3}$ before the experiments were conducted. In addition, the pipes were insulated with glass wool to reduce heat loss.

Table 2. Reactor and catalyst parameters.

\begin{tabular}{cc}
\hline Parameter/Unit & Value \\
\hline Cell density/cell/in ${ }^{-2}$ & 400 \\
Coating thickness/mm & 0.025 \\
Carrier length/mm & 20 \\
Temperature/K & $373-873$ \\
Cu loading/wt $\%$ & 2 \\
Washcoat porosity & 0.5 \\
Pore diameter/nm & 0.56 \\
\hline
\end{tabular}




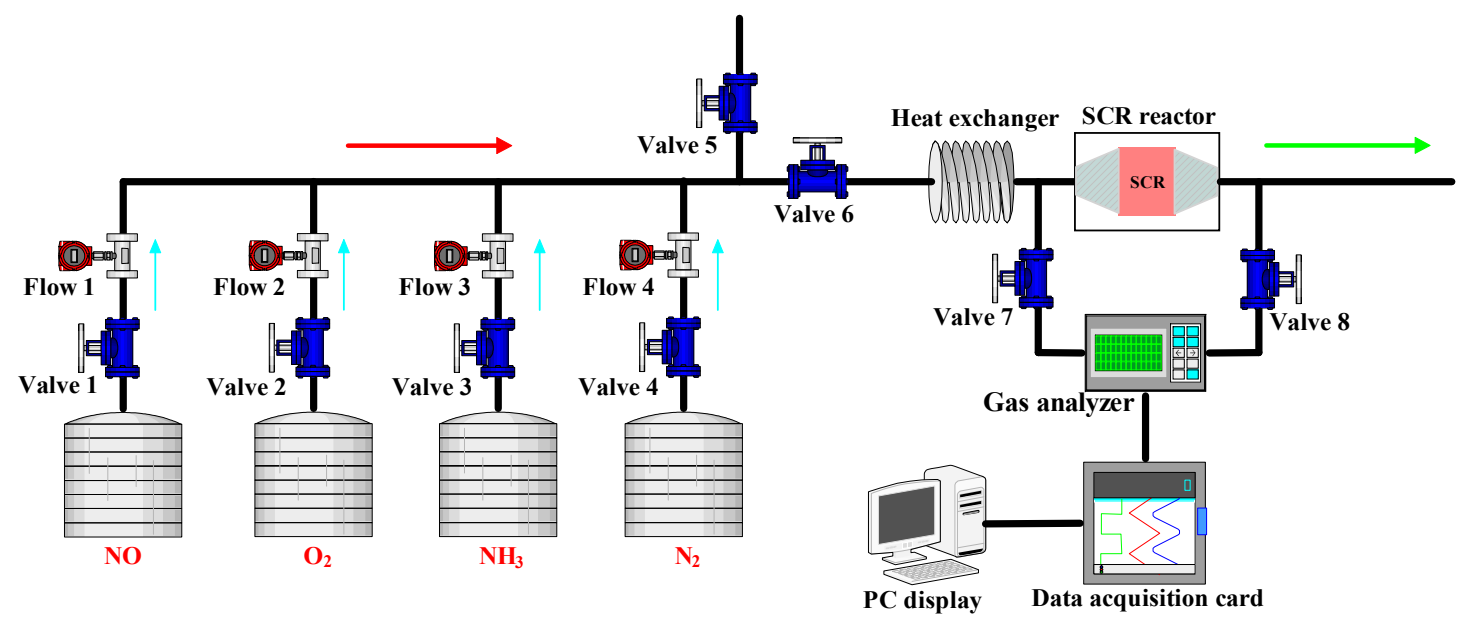

Figure 4. Schematic diagram of diesel engine test device.

The SCR reaction kinetic simulation model of $\mathrm{Cu}$ molecular zeolite catalyst was established in this paper and included mainly seven steps of the total reaction. The simulation results were optimized by adjusting the kinetic parameters such as pre-factor and activation energy in the model until the experimental results agreed with the simulation results. At the outlet, the experiment and simulation $\mathrm{NO}$ and $\mathrm{NH}_{3}$ concentrations in the standard SCR oxidation reaction are shown in Figure 5. It could be seen that the concentration errors of $\mathrm{NO}$ and $\mathrm{NH}_{3}$ at the outlet of experimental measurement and simulation calculation were within $5 \%$, which indicated that the model could accurately predict the SCR reaction.

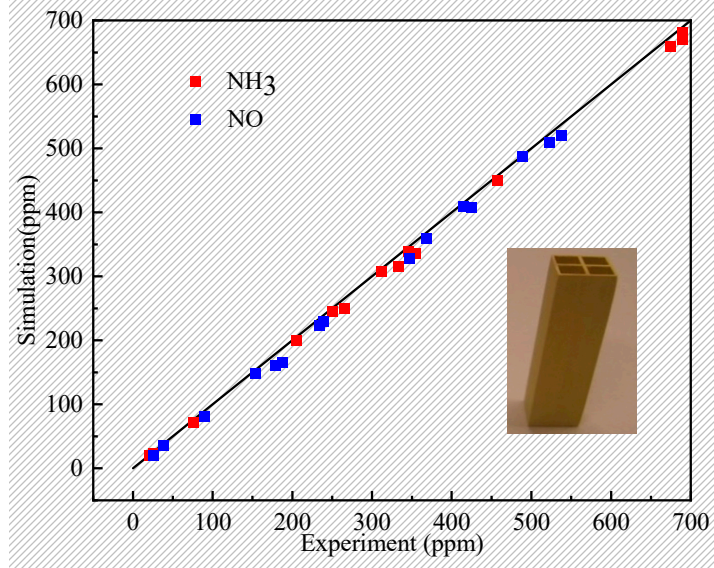

Figure 5. Comparison of $\mathrm{NO}$ and $\mathrm{NH}_{3}$ concentrations calculated by experiment and simulation at the reaction outlet.

\section{Results and Discussion}

\subsection{Axial Distribution of SCR Catalytic Reaction}

$\mathrm{NH}_{3}$ with molar concentrations of $500 \times 10^{-6}$, NO with molar concentrations of $500 \times 10^{-6}, 2 \% \mathrm{H}_{2} \mathrm{O}$, and $5 \% \mathrm{O}_{2}$ were added to the $\mathrm{SCR}$ reactor. The $\mathrm{NH}_{3}$ concentration, $\mathrm{NO}_{\mathrm{x}}$ concentration, and $\mathrm{NO}_{\mathrm{x}}$ conversion in the axial direction of the catalyst under inlet conditions were simulated and studied in the steady-state standard SCR reaction, rapid SCR reaction, and $\mathrm{NO}_{2}-\mathrm{SCR}$ reaction $[42,43]$.

\subsubsection{Standard SCR Reaction}

(1) $\mathrm{NH}_{3}$ concentration

The variation of axial $\mathrm{NH}_{3}$ concentration under standard $\mathrm{SCR}$ reaction condition at a steady state is shown in Figure 6. It can be seen that the concentration of $\mathrm{NH}_{3}$ changes 
little at low temperatures. More specifically, with the variation of catalyst position, the effect is not obvious at $180^{\circ} \mathrm{C}$. It is due to the lower low-temperature activity of the $\mathrm{Cu}$ zeolite catalyst. When the temperature of the reactor exceeds $280^{\circ} \mathrm{C}$, the $\mathrm{NH}_{3}$ concentration gradually decreases with the increase of catalyst position. This is due to the higher lowtemperature activity of the $\mathrm{Cu}$ zeolite catalyst at high temperatures. Thus, the concentration of $\mathrm{NH}_{3}$ decreases with the increase of catalyst position. In addition, Komatsu et al. [44] suggested that $\mathrm{Cu}$ particles increased the concentration of $\mathrm{NO}_{2}$, which reacted with $\mathrm{NH}_{3}$ and produced $\mathrm{N}_{2}$ and $\mathrm{H}_{2} \mathrm{O}$, thus reducing the $\mathrm{NH}_{3}$ concentration. Thus, the higher the temperature, the more $\mathrm{NH}_{3}$ concentration decreases. Auvary et al. [32] and Gong et al. [45] have similar conclusions.

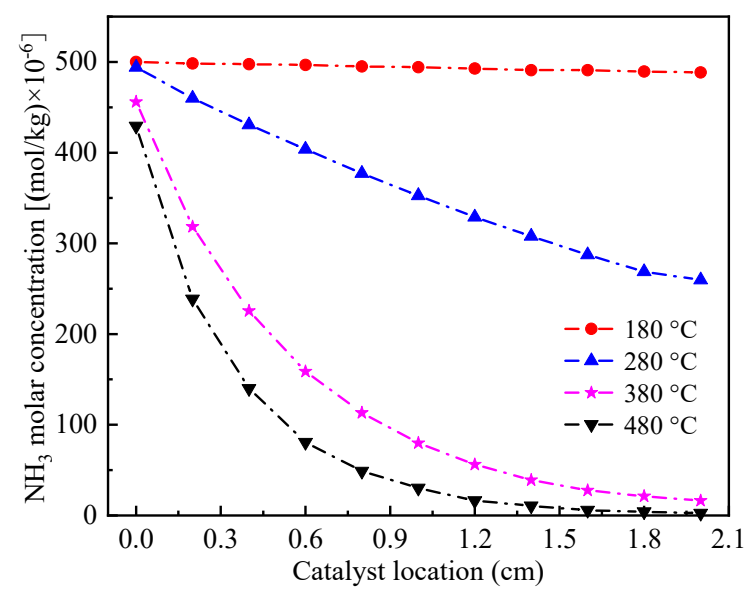

Figure 6. Variation of axial $\mathrm{NH}_{3}$ concentration under standard SCR reaction.

(2) $\mathrm{NO}_{x}$ concentration

Figure 7 shows the variation of catalyst axial $\mathrm{NO}_{x}$ concentration under standard SCR reaction condition at a steady state. It can be seen that the $\mathrm{NO}_{x}$ concentration changes little at low temperatures. With the increase of temperature, the $\mathrm{NO}_{\mathrm{x}}$ conversion increases due to the increasing gradually activity of the $\mathrm{Cu}$ zeolite catalyst. Between $380^{\circ} \mathrm{C}$ and $480^{\circ} \mathrm{C}$, $\mathrm{NO}_{x}$ on the $\mathrm{Cu}$ zeolite catalyst surface can be almost completely converted, resulting in the decrease of $\mathrm{NO}_{x}$ concentration. More specifically, at catalyst position of $1.0 \mathrm{~cm}$, the conversion efficiency has reached more than $85 \%$. When the catalyst position is $1.9 \mathrm{~cm}, 95 \%$ of the $\mathrm{NO}_{x}$ has been converted. Henry et al. [33] had a similar conclusion. Therefore, the length of the catalyst can be reasonably selected.

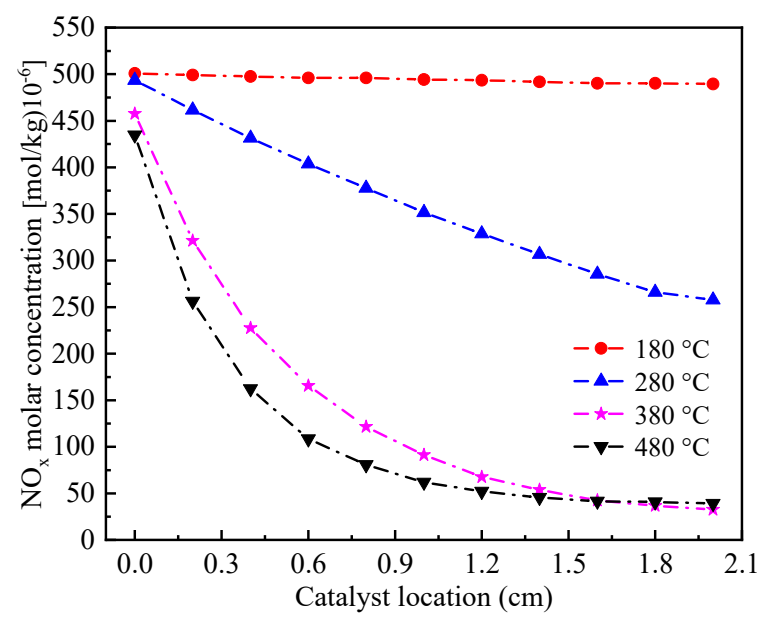

Figure 7. Variation of axial $\mathrm{NO}_{\mathrm{x}}$ concentration under standard SCR reaction. 


\section{(3) $\mathrm{NO}_{\mathrm{x}}$ conversion}

The variation of axial $\mathrm{NO}_{\mathrm{x}}$ conversion under standard SCR reaction conditions at a steady state are shown in Figure 8. It can be seen that the concentration of $\mathrm{NO}_{\mathbf{x}}$ changes little at low temperatures. Only when the temperature in the reactor exceeds $280{ }^{\circ} \mathrm{C}$, the activity of the catalyst increases significantly. More specifically, when the temperature reaches $380{ }^{\circ} \mathrm{C}$, the conversion rate has reached more than $95 \%$ at $1.2 \mathrm{~cm}$. Metkar et al. [46] and Xue et al. [47] also proved that the higher the temperature, the higher the $\mathrm{NO}_{\mathrm{x}}$ conversion efficiency. In addition, it can be found that the SCR reaction is mainly concentrated in the first half part of the reactor, and the influence of the rear section is small. Therefore, the length of the reactor can be reasonably selected to optimize its structure.

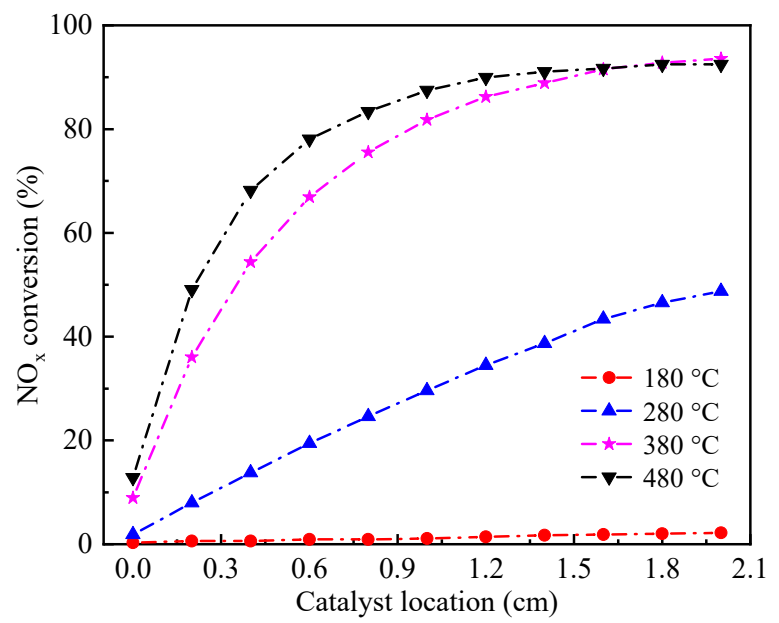

Figure 8. Variation of axial $\mathrm{NO}_{\mathrm{x}}$ conversion under standard $\mathrm{SCR}$ reaction.

\subsubsection{Fast SCR Reaction}

(1) $\mathrm{NH}_{3}$ concentration

The variation of $\mathrm{NH}_{3}$ concentration in the axial direction of the catalyst under fast SCR reaction conditions at a steady state is shown in Figure 9. Compared with standard SCR reaction (Seen Figure 6), the $\mathrm{NH}_{3}$ concentration of fast SCR reaction is also significantly transformed at low temperatures. Moreover, the $\mathrm{NH}_{3}$ concentration decreases faster in the first half of the catalyst. In addition, the concentration of $\mathrm{NH}_{3}$ is lower than that of $\mathrm{NO}_{\mathrm{x}}$. This is due to the reduction of $\mathrm{NH}_{3}$ concentration due to the existence of an $\mathrm{NH}_{3}$ oxidation reaction. Metkar et al. [48] and Lu et al. [49] have similar experimental conclusions.

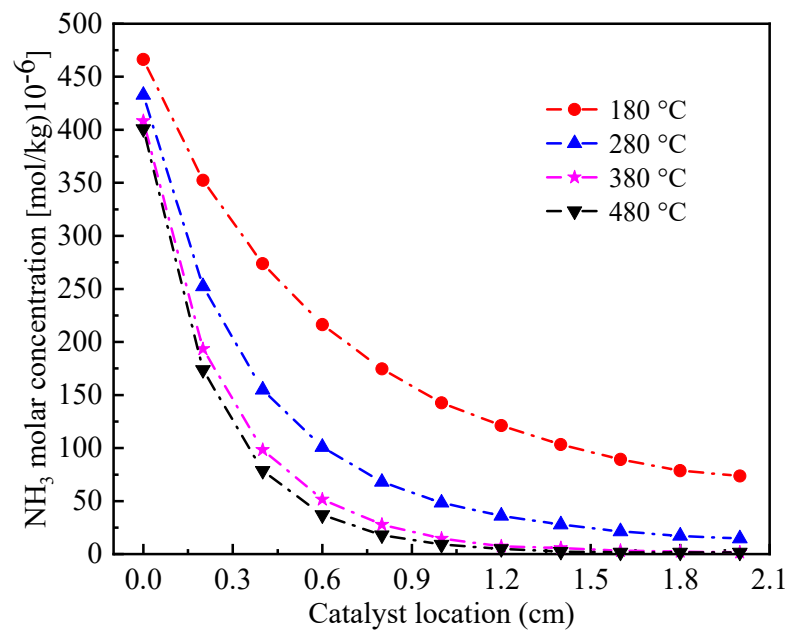

Figure 9. Variation of axial $\mathrm{NH}_{3}$ concentration under fast $\mathrm{SCR}$ reaction. 


\section{(2) $\mathrm{NO}_{x}$ concentration}

Figure 10 shows the catalyst axial $\mathrm{NO}_{x}$ concentration variation under the fast $\mathrm{SCR}$ reaction condition in a steady state. Compared with the standard SCR, $\mathrm{NO}_{\mathrm{x}}$ in the first half of the reactor is also significantly converted in the fast SCR reaction, and the speed of the fast SCR reaction is faster. This is because the $\mathrm{NO}_{x}$ conversion activity of the zeolite catalyst gradually increases with the increase of temperature under the fast reaction. Activity has been greatly improved. Meanwhile, the concentration of $\mathrm{NO}_{\mathrm{x}}$ in the reactor is higher than that of $\mathrm{NH}_{3}$ due to an $\mathrm{NH}_{3}$ oxidation reaction (Figure 9).

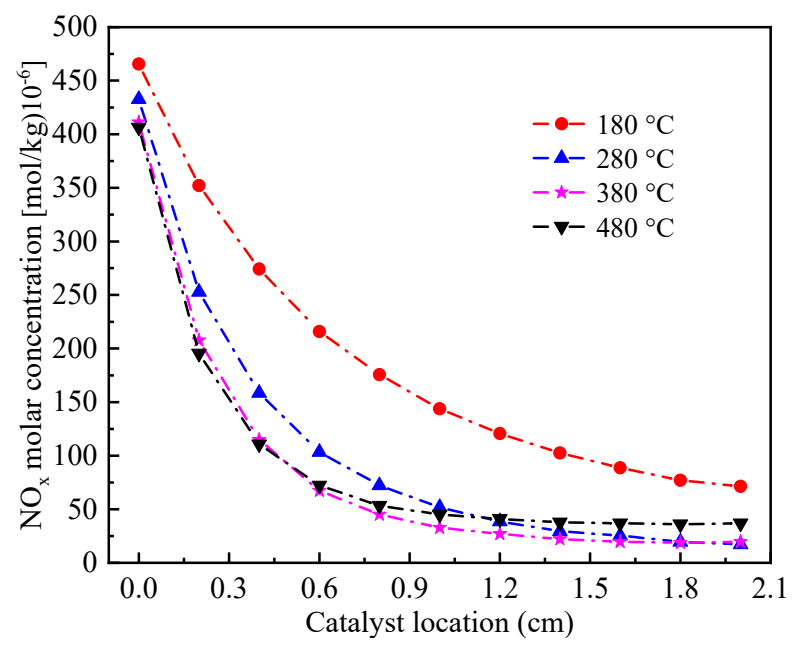

Figure 10. Variation of axial $\mathrm{NO}_{\mathrm{x}}$ concentration under fast SCR reaction.

\section{(3) $\mathrm{NO}_{\mathrm{x}}$ conversion}

Figure 11 shows the catalyst axial $\mathrm{NO}_{x}$ conversion variation under the fast SCR reaction condition in a steady state. It can be seen that the $\mathrm{NO}_{x}$ conversion rate of the fast SCR reaction increases gradually at all temperatures. It is because the presence of $\mathrm{NO}_{2}$ in the reaction improves the $\mathrm{NO}_{x}$ conversion efficiency and the reaction is much faster than the standard SCR reaction. In addition, with the increase of catalyst position, the conversion increases gradually. This shows that the activity of $\mathrm{Cu}$-based catalysts is enhanced under fast reaction. At the same temperature, the position dependence of the rapid SCR reaction on the catalyst decreases (after $0.9 \mathrm{~cm}$, the effect is small), which may be due to the higher total conversion caused by the mixed reaction control.

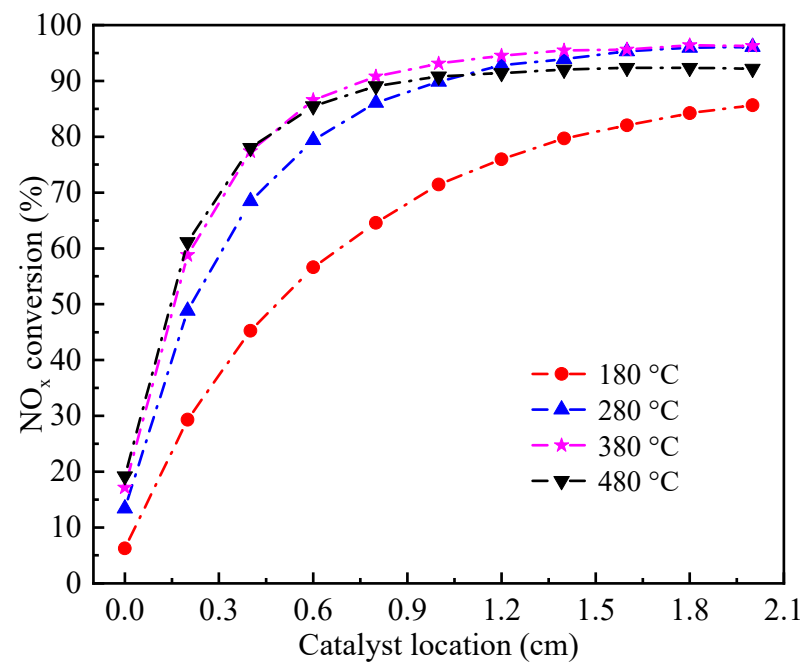

Figure 11. Variation of axial $\mathrm{NO}_{\mathrm{x}}$ conversion under fast SCR reaction. 


\subsection{3. $\mathrm{NO}_{2}$-SCR Reaction}

(1) $\mathrm{NO}_{\mathrm{x}}$ concentration

The variation of catalyst axial $\mathrm{NO}_{2}$ concentration under $\mathrm{NO}_{2}-\mathrm{SCR}$ reaction condition in a steady state are shown in Figure 12. It can be seen that more $\mathrm{NO}_{2}$ will be produced at $180-280{ }^{\circ} \mathrm{C}$, and the concentration of $\mathrm{NO}_{2}$ increases with the increase of reactor location. However, there is less $\mathrm{NO}_{2}$ in the high-temperature stage. This is because the oxidation reaction of NO is reversible. At low temperature, the reaction rate is controlled by reaction kinetics, while at high temperature, the reaction is controlled by reaction equilibrium, and $\mathrm{NO}_{2}$ decomposes to produce NO. For example, Shi et al. [50] reached a similar conclusion. In addition, it can be found that the concentration of $\mathrm{NO}_{2}$ remains unchanged when the reactor position is $0.6 \mathrm{~cm}$ at high temperatures $\left(380-480{ }^{\circ} \mathrm{C}\right)$.

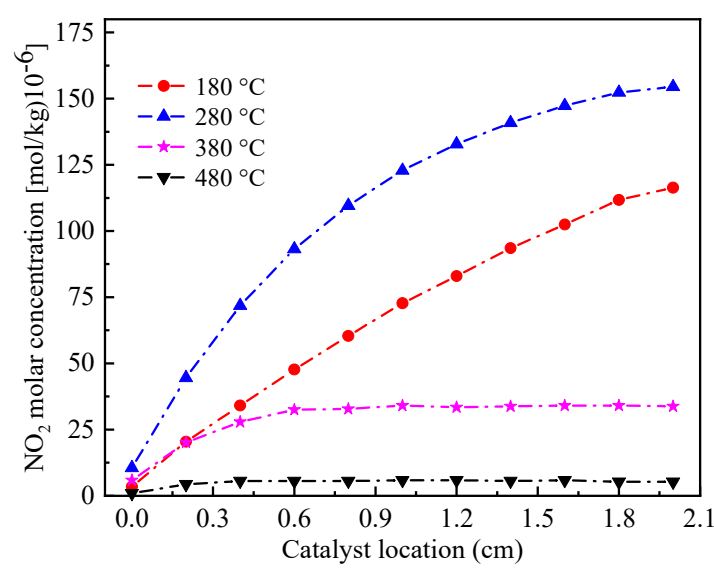

Figure 12. Variation of axial $\mathrm{NO}_{x}$ concentration under $\mathrm{NO}_{2}-\mathrm{SCR}$ reaction condition.

\section{(2) $\mathrm{NO}_{\mathrm{x}}$ conversion}

The variation of catalyst axial $\mathrm{NO}_{x}$ conversion under $\mathrm{NO}_{2}-\mathrm{SCR}$ reaction condition in a steady state are shown in Figure 13. It can be seen that the presence of $\mathrm{NO}_{2}$ improves the overall conversion of $\mathrm{NO}_{\mathrm{x}}$. However, $\mathrm{NO}_{2}-\mathrm{SCR}$ reaction is faster than standard SCR but slower than the fast SCR. In addition, $\mathrm{NO}_{2}$-SCR reaction is mainly concentrated in the first half of the catalytic reactor, and there is only a slight increase in the second half. Moreover, at $280-480^{\circ} \mathrm{C}$, the $\mathrm{NO}_{\mathrm{x}}$ conversion rate is relatively high. This shows that the catalytic activity increases gradually with the increase of temperature. $\mathrm{NO}_{\mathrm{x}}$ reacts from $280^{\circ} \mathrm{C}$, and the conversion rate increases gradually with the increase of the position of the catalyst. Finally, it tends to be stable. In addition, it can be seen from Figure 13 that the conversion efficiency of $\mathrm{NO}_{x}$ is the best at the position of $1.2 \mathrm{~cm}$.

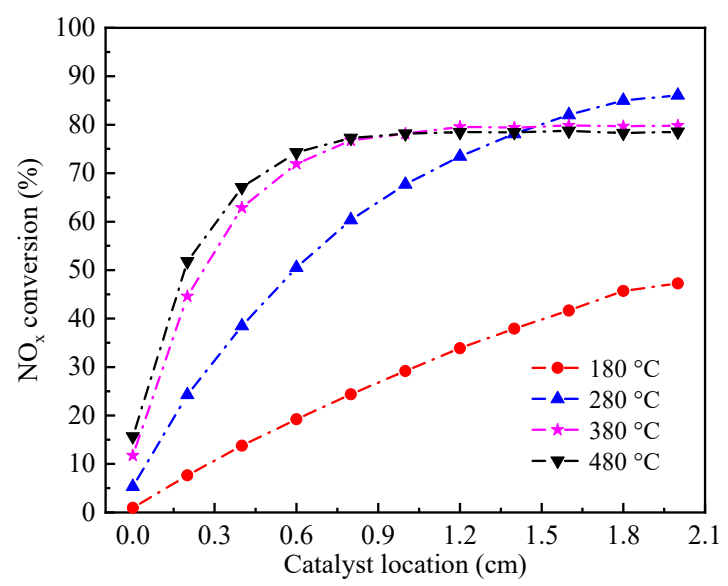

Figure 13. Variation of axial $\mathrm{NO}_{x}$ conversion under $\mathrm{NO}_{2}-\mathrm{SCR}$ reaction condition. 


\subsection{Reaction Conditions of Different SCR Channel Cross-Sections}

In order to further improve the heat and mass transfer of the SCR channel, three different structures of SCR channels were designed and then calculated and simulated to optimize the performance of each SCR channel. The first structure is a square channel, the second structure is a rectangular channel, and the third structure is a hexagonal channel. The wall thickness $C$ of the three channels is $0.7 \mathrm{~mm}$, and the length $A$ and width B are shown in Figure 14. Under the same boundary condition, the effects of different length-width ratio structures on SCR channel performance are studied using the verified simulation model in term of pressure drop, $\mathrm{NH}_{3}$ conversion, and $\mathrm{NO}_{\mathrm{x}}$ conversion are discussed.

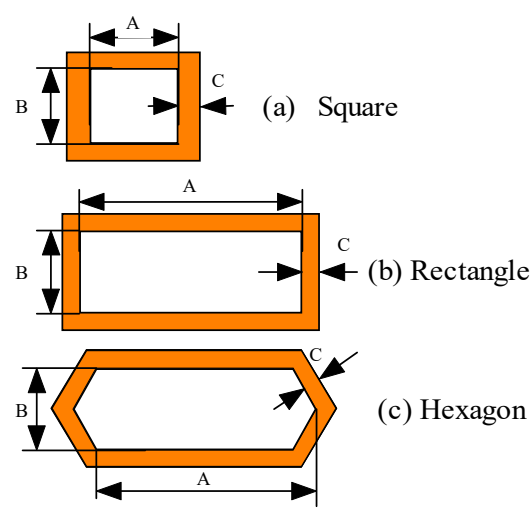

Figure 14. Sectional area dimension of SCR channel (length-width ratio $=A / B, C$ is wall thickness).

Based on the calculation results of square $(A=4.0 \mathrm{~mm})$, rectangular channels with different width B (3.0-3.6 mm) and different length-width ratios A/B (1-10) are selected in the paper. The established simulation model is used for simulation calculation, and the $\mathrm{NO}$ conversion, $\mathrm{NH}_{3}$ conversion, and pressure drop results of the relative square channel $(\mathrm{A}=4.0 \mathrm{~mm})$ with the same wall thickness and different rectangular channels are obtained, as shown in Figure 15a-c.

It can be seen that with the increase of length-width ratio, the relative pressure drop, relative $\mathrm{NO}$ conversion, and relative $\mathrm{NH}_{3}$ conversion all show a decreasing trend. When the length-width ratio is greater than 5 , the length-width ratio has little effect on the relative pressure drop, relative $\mathrm{NO}$ conversion, and $\mathrm{NH}_{3}$ conversion. This also shows that when selecting rectangular or square channels, the interval with a length-width ratio of 1-5 is a range worthy of consideration. For example, compared with square $(\mathrm{A}=4.0)$, when the length-width ratio is 2 , the relative pressure drop, relative $\mathrm{NH}_{3}$ conversion, and relative NO conversion ratio of the rectangle $(\mathrm{A}=3.2)$ are reduced by $6.8 \%, 0.15 \%$, and $0.12 \%$, respectively. Meanwhile, with the increase of width $\mathrm{A}$, the relative pressure drop, relative $\mathrm{NO}$ conversion, and relative $\mathrm{NH}_{3}$ conversion decreased.

A significant disadvantage of square and rectangular channels is that the adjacent edges intersect at a right angle. It is unfavorable for gas flow. Thus, the gas pressure drop is increased, and the reduction efficiency of nitrogen oxides is reduced in the channel. In addition, sharp right-angle edges are easy to be block, resulting in the failure of SCR porous media channel. In order to overcome this deficiency, this paper changes the rectangular channel with $90^{\circ}$ edge to the hexagonal channel with $120^{\circ}$ edge. The chemical reaction of gas will be improved due the improvement of gas flow. The velocity cross-section distribution of gas passing through the rectangular and hexagonal channels under the same boundary conditions is shown in Figure 16. It can be seen that the gas flow field distribution in the hexagonal channel is more uniform than that in the rectangular channel. At the corner of the rectangular channel, the flow rate of a large part of the reaction gas is very low or even stagnant. Therefore, more dead zones of gas reaction with catalyst are formed at the corner of the rectangular channel. Among them, the area where the cross-section velocity of the rectangular channel is less than $5 \mathrm{~m} / \mathrm{s}$ accounts for $38 \%$. Compared with rectangular 
channel, the area where the cross-section velocity of the hexagonal channel is less than $5 \mathrm{~m} / \mathrm{s}$ accounts for $33 \%$. Thus, the hexagonal channel can effectively increase the diffusion rate of gas reactants to the catalyst wall to improve the catalytic conversion efficiency.
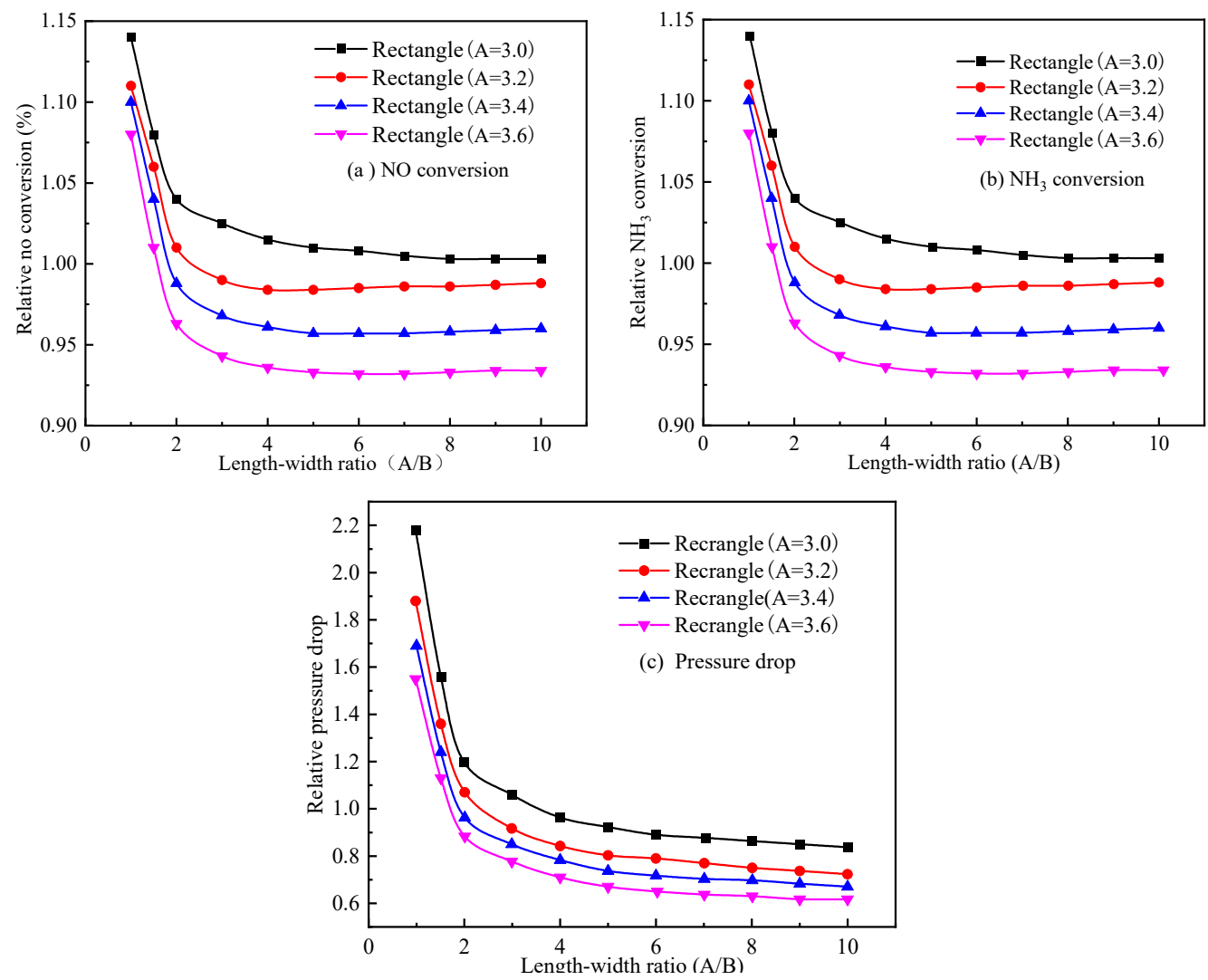

Figure 15. Relative $\mathrm{NO}$ conversion, relative $\mathrm{NH}_{3}$ conversion, and relative pressure drop changes relative to square channel and rectangular channel, (a) Relative NO conversion, (b) Relative $\mathrm{NH}_{3}$ conversion, (c) Relative pressure drop.
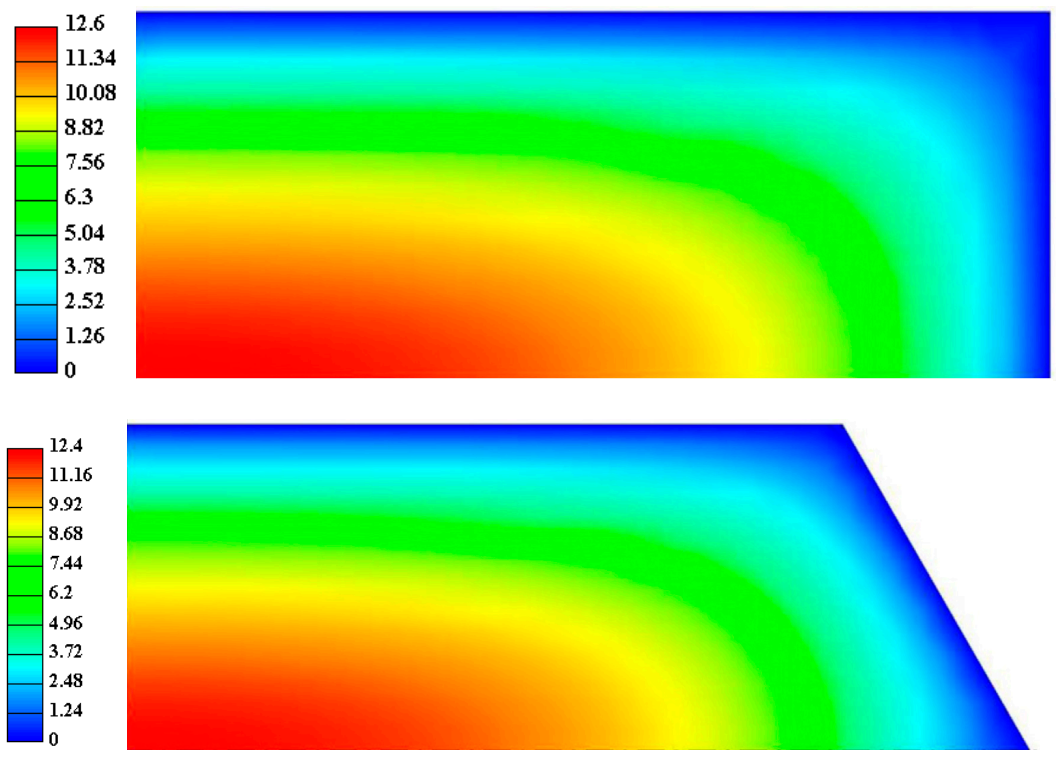

Figure 16. Velocity distribution of rectangular and hexagonal channels with the same wall thickness.

The relative $\mathrm{NO}$ conversion, relative $\mathrm{NH}_{3}$ conversion, and relative pressure drop for the rectangular and hexagonal channels relative to the square channel are shown in Figure 17a-c. It can be found that the hexagonal channel further enhances the heat and 
mass transfer between the gas and the catalyst wall and reduces the pressure drop of the gas in the channel when the length-width ratio and wall thickness are constant. For example, compared with the square channel $(\mathrm{A}=4.0)$, the relative pressure drop of the designed hexagonal channel is reduced by $9.6 \%$, and the relative $\mathrm{NO}$ conversion and relative $\mathrm{NH}_{3}$ conversion are increased by $0.51 \%$ and $0.48 \%$. Therefore, a reasonable selection of structural parameters of SCR catalysts can effectively optimize the SCR catalyst system.
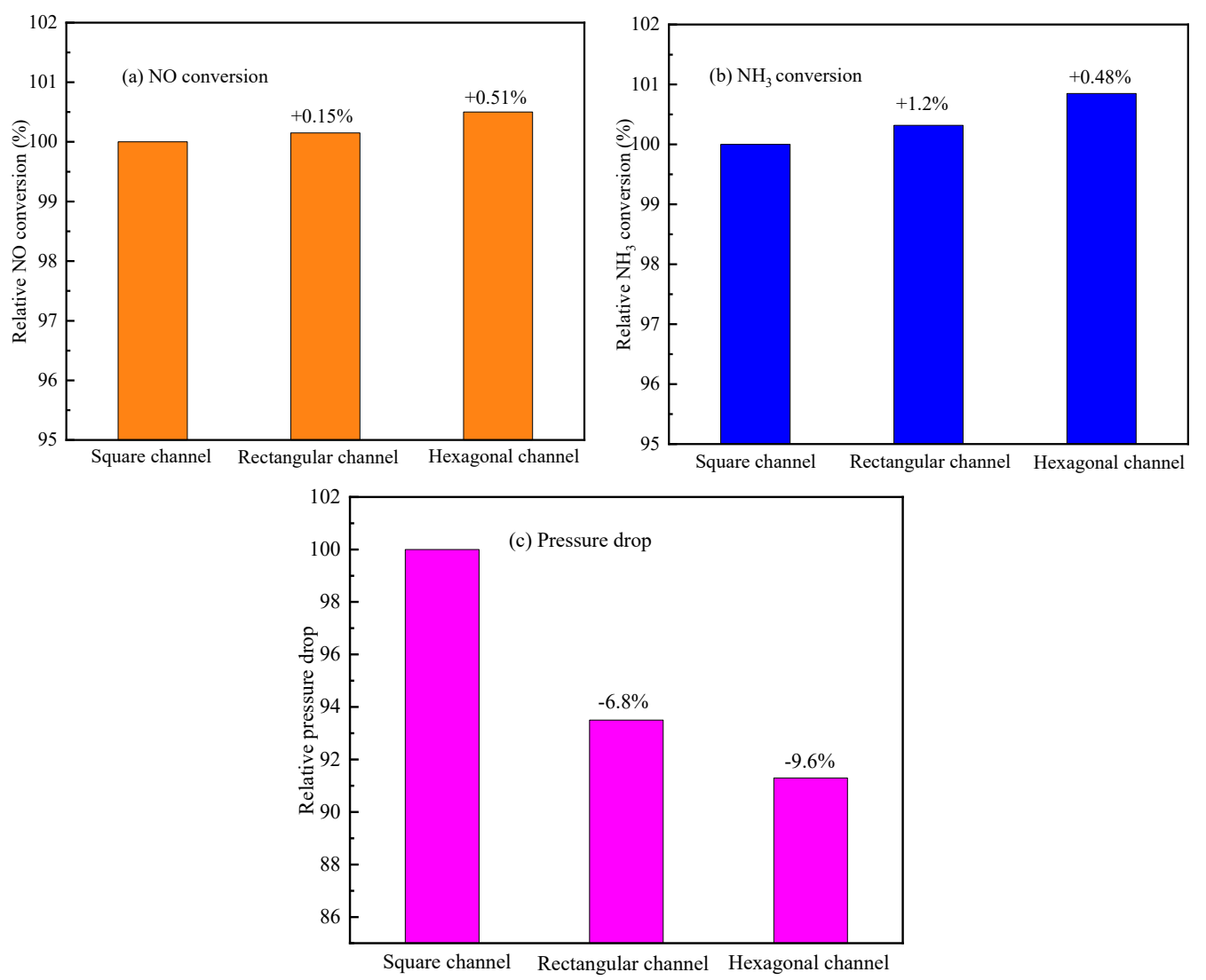

Figure 17. Relative $\mathrm{NO}$ conversion, $\mathrm{NH}_{3}$ conversion, and pressure drop for rectangular and hexagonal channels relative to square channels, (a) Relative NO conversion, (b) Relative $\mathrm{NH}_{3}$ conversion, (c) Relative pressure drop.

\section{Conclusions}

With the increasingly stringent emission regulations due to energy crisis [51-57] and environmental problems [58-68], how to effectively reduce $\mathrm{NO}_{\mathrm{x}}$ emission from a diesel engine has become a concern [69]. In order to reduce the $\mathrm{NO}_{\mathrm{x}}$ emission, the kinetic model of $\mathrm{NH}_{3}$-SCR reaction over $\mathrm{Cu}-\mathrm{ZSM}-5$ catalyst was established in this paper. Firstly, the $\mathrm{NH}_{3}$ concentration, $\mathrm{NO}_{x}$ concentration, and $\mathrm{NO}_{x}$ conversion rate variation laws along the axis were analyzed. Secondly, the relative pressure drops, relative $\mathrm{NH}_{3}$ conversions, and relative $\mathrm{NO}_{x}$ conversion efficiencies of different SCR channels were studied. Finally, the main conclusions were as follows:

(1) The improved model can better predict the catalytic reaction of the diesel SCR system.

(2) The Cu-based zeolite catalyst is of poor low-temperature characteristics and good high-temperature activity.

(3) $\mathrm{NH}_{3}$-SCR catalytic reaction is mainly concentrated in the first half of the reactor, and the influence of the second half is little.

(4) The hexagonal channel can effectively increase the diffusion rate of gas reactants to the catalyst wall, reduce the pressure drop and improve the catalytic conversion efficiencies of $\mathrm{NH}_{3}$ and $\mathrm{NO}_{\mathrm{x}}$. 
Author Contributions: Conceptualization, S.Y. and J.Z.; software, S.Y.; formal analysis, S.Y. and J.Z.; investigation, S.Y. and J.Z.; resources, J.Z.; writing-original draft preparation, S.Y. and J.Z.; writing-review and editing, S.Y. and J.Z.; supervision, J.Z.; funding acquisition, J.Z. All authors have read and agreed to the published version of the manuscript.

Funding: This work is supported by the Natural Science Foundation of Jiangsu Province under the research grant BK20191205 in China; the work is supported by the Natural Science Foundation of Guangxi under the research grants of 2018GXNSFAA281267 and 2018 GXNSFAA 294072.

Data Availability Statement: All data used to support the findings of this study are included within the article.

Conflicts of Interest: The authors declare that they have no conflict of interests regarding the publication of this paper.

\section{References}

1. Zhang, Z.; E, J.; Chen, J.; Zhu, H.; Zhao, X.; Han, D.; Zuo, W.; Peng, Q.; Gong, J.; Yin, Z. Effects of low-level water addition on spray, combustion and emission characteristics of a medium speed diesel engine fueled with biodiesel fuel. Fuel 2018, 239, 245-262. [CrossRef]

2. Emiroğlu, A.O. Effect of fuel injection pressure on the characteristics of single cylinder diesel engine powered by butanol-diesel blend. Fuel 2019, 256, 115928. [CrossRef]

3. Zhang, Z.; E, J.; Chen, J.; Zhao, X.; Zhang, B.; Deng, Y.; Peng, Q.; Yin, Z. Effects of boiling heat transfer on the performance enhancement of a medium speed diesel engine fueled with diesel and rapeseed methyl ester. Appl. Therm. Eng. 2020, 169, 114984. [CrossRef]

4. Zhang, Z.; Ye, J.; Tan, D.; Feng, Z.; Luo, J.; Tan, Y.; Huang, Y. The effects of $\mathrm{Fe}_{2} \mathrm{O}_{3}$ based DOC and SCR catalyst on the combustion and emission characteristics of a diesel engine fueled with biodiesel. Fuel 2021, 290, 120039. [CrossRef]

5. E, J.; Zhao, X.; Liu, G.; Zhang, B.; Zuo, Q.; Wei, K.; Li, H.; Han, D.; Gong, J. Effects analysis on optimal microwave energy consumption in the heating process of composite regeneration for the diesel particulate filter. Appl. Energy 2019, $254,113736$. [CrossRef]

6. Di Benedetto, A. Modeling and simulation of soot combustion dynamics in a catalytic diesel particulate filter. Chem. Eng. Sci. 2015, 137, 69-78.

7. Li, W.; Ji, J.; Huang, L.; Guo, Z. Global dynamics of a controlled discontinuous diffusive SIR epidemic system. Appl. Math. Lett. 2021, 121, 107420. [CrossRef]

8. Rogóż, R.; Kapusta, J.; Bachanek, J.; Vankan, J.; Teodorczyk, A. Improved urea-water solution spray model for simulations of selective catalytic reduction systems. Renew. Sustain. Energy Rev. 2019, 120, 109616. [CrossRef]

9. E, J.; Zhao, X.; Qiu, L.; Wei, K.; Zhang, Z.; Deng, Y.; Han, D.; Liu, G. Experimental investigation on performance and economy characteristics of a diesel engine with variable nozzle turbocharger and its application in urban bus. Energy Convers. Manag. 2019, 193, 149-161. [CrossRef]

10. Zhang, Z.; E, J.; Deng, Y.; Pham, M.; Zuo, W.; Peng, Q.; Yin, Z. Effects of fatty acid methyl esters proportion on combustion and emission characteristics of a biodiesel fueled marine diesel engine. Energy Convers. Manag. 2018, 159, 244-253. [CrossRef]

11. Tan, D.; Chen, Z.; Li, J.; Luo, J.; Yang, D.; Cui, S.; Zhang, Z. Effects of Swirl and Boiling Heat Transfer on the Performance Enhancement and Emission Reduction for a Medium Diesel Engine Fueled with Biodiesel. Processes 2021, 9, 568. [CrossRef]

12. E, J.; Liu, G.; Zhang, Z.; Han, D.; Chen, J.; Gong, J.; Yin, Z. Effect analysis on cold starting performance of a diesel engine fueled with biodiesel fuel based on an improved thermodynamic model. Appl. Energy 2019, 243, 321-335. [CrossRef]

13. Guan, B.; Zhan, R.; Lin, H.; Huang, Z. Review of state of the art technologies of selective catalytic reduction of NOx from diesel engine exhaust. Appl. Therm. Eng. 2014, 66, 395-414. [CrossRef]

14. Cai, T.; Zhao, D. Effects of fuel composition and wall thermal conductivity on thermal and NOx emission performances of an ammonia/hydrogen-oxygen micro-power system. Fuel Process. Technol. 2020, 209, 106527. [CrossRef]

15. Zhang, Z.; Tian, J.; Li, J.; Ji, H.; Tan, D.; Luo, J.; Jiang, Y.; Yang, D.; Cui, S. Effects of Different Mixture Ratios of Methanol-Diesel on the Performance Enhancement and Emission Reduction for a Diesel Engine. Processes 2021, 9, 1366. [CrossRef]

16. Zhang, Z.; Li, J.; Tian, J.; Xie, G.; Tan, D.; Qin, B.; Huang, Y.; Cui, S. Effects of Different Diesel-Ethanol Dual Fuel Ratio on Performance and Emission Characteristics of Diesel Engine. Processes 2021, 9, 1135. [CrossRef]

17. Wang, X.; Zhang, R.; Wang, H.; Wei, Y. Strategy on Effective Synthesis of SSZ-13 Zeolite Aiming at Outstanding Performances for $\mathrm{NH}_{3}$-SCR Process. Catal. Surv. Asia 2020, 24, 143-155. [CrossRef]

18. Xue, H.; Guo, X.; Meng, T.; Guo, Q.; Mao, D.; Wang, S. Cu-ZSM-5 Catalyst Impregnated with Mn-Co Oxide for the Selected Catalytic Reduction of NO: Physicochemical Property-Catalytic Activity Relationship and In Situ DRIFTS Study for the Reaction Mechanism. ACS Catal. 2021, 11, 7702-7718. [CrossRef]

19. Naicker, T.; Friedrich, H.B. Hexane activation over vanadium modified zeolite ZSM-5. J. Porous Mater. 2012, 20 , 763-775. [CrossRef] 
20. Zhong, C.; Tan, J.; Zuo, H.; Wu, X.; Wang, S.; Liu, J. Synergy effects analysis on CDPF regeneration performance enhancement and NOx concentration reduction of NH3-SCR over Cu-ZSM-5. Energy 2021, 230, 120814. [CrossRef]

21. E, J.; Zhang, Z.; Chen, J.; Pham, M.; Zhao, X.; Peng, Q.; Zhang, B.; Yin, Z. Performance and emission evaluation of a marine diesel engine fueled by water biodiesel-diesel emulsion blends with a fuel additive of a cerium oxide nanoparticle. Energy Convers. Manag. 2018, 169, 194-205. [CrossRef]

22. Cheng, M.; Jiang, B.; Yao, S.; Han, J.; Zhao, S.; Tang, X.; Zhang, J.; Wang, T. The Mechanism of $\mathrm{NH}_{3}-\mathrm{SCR} \mathrm{Reaction}_{\text {for NOx }}$ Removal from Diesel Engine Exhaust and Hydrothermal Stability of Cu-Mn/Zeolite Catalysts. J. Phys. Chem. C 2017, $122,1-35$.

23. Fu, G.; Chen, J.; Liang, Y.; Li, R.; Yang, X.; Jiang, J. Cu-IM-5 as the Catalyst for Selective Catalytic Reduction of NOx with NH3: Role of Cu Species and Reaction Mechanism. Catalysts 2021, 11, 221. [CrossRef]

24. Rajasekar, V.; Ashok, B. Critical interpretative review on current outlook and prospects of selective catalytic reduction system for De-NOx strategy in compression ignition engine. Fuel 2020, 276, 117996.

25. Grossale, A.; Nova, I.; Tronconi, E. Study of a Fe-zeolite-based system as NH3-SCR catalyst for diesel exhaust aftertreatment. Catal. Today 2008, 136, 18-27. [CrossRef]

26. Chapman, D.M. Behavior of titania-supported vanadia and tungsta SCR catalysts at high temperatures in reactant streams: Tungsten and vanadium oxide and hydroxide vapor pressure reduction by surficial stabilization. Appl. Catal. A: Gen. 2011, 392, 143-150. [CrossRef]

27. Iwamoto, M.; Furukawa, H.; Mine, Y.; Uemura, F.; Mikuriya, S.-I.; Kagawa, S. Copper(II) ion-exchanged ZSM-5 zeolites as highly active catalysts for direct and continuous decomposition of nitrogen monoxide. J. Chem. Soc. Chem. Commun. 1986, 1272-1273. [CrossRef]

28. Zhou, D.; Yang, W.; An, H.; Li, J.; Shu, C. A numerical study on RCCI engine fueled by biodiesel/methanol. Energy Convers. Manag. 2014, 89, 798-807. [CrossRef]

29. Na, H.; Reed, D.C.; Annaswamy, A.M.; Laing, P.M.; Kolmanovsky, I. Control-Oriented Reduced-Order Models for Urea Selective Catalytic Reduction Systems Using a Physics-Based Approach. In Proceedings of the SAE 2011 World Congress \& Exhibition, Warrendale, PA, USA, 12-14 April 2011. [CrossRef]

30. Zhong, C.; Gong, J.; Tan, L.; Liu, W.; Liu, G.; Zhang, Z. Modeling intraphase and interphase mass transfer limitations for NH3-SCR over Cu-ZSM-5. Chem. Eng. Sci. 2019, 207, 479-489. [CrossRef]

31. Colombo, M.; Nova, I.; Tronconi, E. Detailed kinetic modeling of the $\mathrm{NH}_{3}-\mathrm{NO} / \mathrm{NO}_{2} \mathrm{SCR}$ reactions over a commercial Cu-zeolite catalyst for Diesel exhausts after treatment. Catal. Today 2012, 197, 243-255. [CrossRef]

32. Auvray, X.; Partridge, W.; Choi, J.-S.; Pihl, J.; Yezerets, A.; Kamasamudram, K.; Currier, N.; Olsson, L. Local ammonia storage and ammonia inhibition in a monolithic copper-beta zeolite SCR catalyst. Appl. Catal. B-Environ. 2012, 126, 144-152. [CrossRef]

33. Henry, C.; Kamasamudram, K.; Currier, N.W.; Yezerets, A.; Castagnola, M.; Chen, H.-Y. Axially Resolved Performance of Cu-Zeolite SCR Catalysts. SAE Int. J. Engines 2012, 5, 975-984. [CrossRef]

34. Hawthorn, R.D. Afterburner catalysts effects of heat and mass transfer between gas and catalyst surface. Recent Adv. Air Pollut. 1974, 70, 428-438.

35. Kong, W.; Zhu, H.; Fei, Z.; Lin, Z. A modified dusty gas model in the form of a Fick's model for the prediction of multicomponent mass transport in a solid oxide fuel cell anode. J. Power Sources 2012, 206, 171-178. [CrossRef]

36. Hayes, R.; Kolaczkowskib, S.; Li, P.; Awdry, S. Evaluating the effective diffusivity of methane in the washcoat of a honeycomb monolith. Appl. Catal. B Environ. 2000, 25, 93-104. [CrossRef]

37. Epstein, N. On tortuosity and the tortuosity factor in flow and diffusion through porous media. Chem. Eng. Sci. 1989, 44, 777-779. [CrossRef]

38. Yuan, J.; Sundén, B. On mechanisms and models of multi-component gas diffusion in porous structures of fuel cell electrodes. Int J. Heat Mass Transf. 2014, 69, 358-374. [CrossRef]

39. Gommes, C.J.; Bons, A.J.; Blacher, S.; Dunsmuir, J.H.; Tsou, A.H. Practical methods for measuring the tortuosity of porous materials from binary or gray-tone tomographic reconstructions. Am. Inst. Chem. Eng. 2009, 55, 2000-2012. [CrossRef]

40. Zhang, F.; Hayes, R.; Kolaczkowski, S. A New Technique to Measure the Effective Diffusivity in a Catalytic Monolith Washcoat. Chem. Eng. Res. Des. 2004, 82, 481-489. [CrossRef]

41. Hu, X.; Yang, M.; Fan, D.; Qi, G.; Wang, J.; Wang, J.; Yu, T.; Li, W.; Shen, M. The role of pore diffusion in determining NH3 SCR active sites over $\mathrm{Cu} / \mathrm{SAPO}-34$ catalysts. J. Catal. 2016, 341, 55-61. [CrossRef]

42. Santos, A.; Bahamonde, A.; Avila, P.; Garcia-Ochoa, F. Measurement of the effective diffusivity for a vanadia-tungstatitania/sepiolite catalyst for SCR of NOx. Appl. Catal. B Environ. 1996, 8, 299-314. [CrossRef]

43. Popovičová, J.; Brusseau, M.L. Dispersion and transport of gas-phase contaminants in dry porous media: Effect of heterogeneity and gas velocity. J. Contam. Hydrol. 1997, 28, 157-169. [CrossRef]

44. Komatsu, T.; Nunokawa, M.; Moon, I.; Takahara, T.; Namba, S.; Yashima, T. Kinetic Studies of Reduction of Nitric Oxide with Ammonia on $\mathrm{Cu}^{2+}$-Exchanged Zeolites. J. Catal. 1994, 148, 427-437. [CrossRef]

45. Gong, J.; Narayanaswamy, K.; Rutland, C.J. Heterogeneous Ammonia Storage Model for NH3-SCR Modeling. Ind. Eng. Chem. Res. 2016, 55, 5874-5884. [CrossRef]

46. Metkar, P.S.; Balakotaiah, V.; Harold, M.P. Experimental study of mass transfer limitations in Fe- and Cu-zeolite-based NH${ }_{3}-\mathrm{SCR}$ monolithic catalysts. Chem. Eng. Sci. 2011, 66, 5192-5203. [CrossRef] 
47. Xue, H.; Meng, T.; Liu, F.; Guo, X.; Wang, S.; Mao, D. Enhanced resistance to calcium poisoning on Zr-modified Cu/ZSM-5 catalysts for the selective catalytic reduction of $\mathrm{NO}$ with $\mathrm{NH}_{3}$. RSC Adv. 2019, 9, 38477-38485. [CrossRef]

48. Metkar, P.S.; Harold, M.P.; Balakotaiah, V. Experimental and kinetic modeling study of $\mathrm{NH}_{3}-\mathrm{SCR}$ of NOx on Fe-ZSM-5, Cuchabazite and combined Fe- and Cu-zeolite monolithic catalysts. Chem. Eng. Sci. 2013, 87, 51-66. [CrossRef]

49. Lu, Y.; Jiang, Z.; Geng, N.; Jiang, S.; Xie, X. Appointment window scheduling with wait-dependent abandonment for elective inpatient admission. Int. J. Prod. Res. 2021, 1-17. [CrossRef]

50. Shi, L.; Si, Z.; Wu, X.; Weng, D.; Wu, Z. Effect of water vapor on NH3-NO/ $\mathrm{NO}_{2} \mathrm{SCR}$ performance of fresh and aged MnOx$\mathrm{NbOx}-\mathrm{CeO}_{2}$ catalysts. J. Environ. Sci. 2015, 31, 240-247.

51. Zuo, H.; Tan, J.; Wei, K.; Huang, Z.; Zhong, D.; Xie, F. Effects of different poses and wind speeds on wind-induced vibration characteristics of a dish solar concentrator system. Renew. Energy 2021, 168, 1308-1326. [CrossRef]

52. Zuo, H.; Liu, G.; Jiaqiang, E.; Zuo, W.; Wei, K.; Hu, W.; Tan, J.; Zhong, D. Catastrophic analysis on the stability of a large dish solar thermal power generation system with wind-induced vibration. Sol. Energy 2019, 183, 40-49. [CrossRef]

53. Hu, L.; Hu, X.; Che, Y.; Feng, F.; Lin, X.; Zhang, Z. Reliable state of charge estimation of battery packs using fuzzy adaptive federated filtering. Appl. Energy 2020, 262, 114569. [CrossRef]

54. Zhang, F.; Liao, G.; E, J.; Chen, J.; Leng, E. Comparative study on the thermodynamic and economic performance of novel absorption power cycles driven by the waste heat from a supercritical $\mathrm{CO}_{2}$ cycle. Energy Convers. Manag. 2021, $228,113671$. [CrossRef]

55. Zuo, H.; Zhang, B.; Huang, Z.; Wei, K.; Tan, J. Effect analysis on SOC values of the power lithium manganate battery during discharging process and its intelligent estimation. Energy 2022, 238, 121854. [CrossRef]

56. E, J.; Zhang, B.; Zeng, Y.; Wen, M.; Huang, Z.; Wei, K.; Chen, J.; Zhu, H.; Deng, Y. Effects analysis on active equalization control of lithium-ion batteries based on intelligent estimation of the state-of-charge. Energy 2022, 238, 121822. [CrossRef]

57. E, J.; Luo, B.; Han, D.; Chen, J.; Liao, G.; Zhang, F.; Ding, J. A comprehensive review on performance improvement of micro energy mechanical system: Heat transfer, micro combustion and energy conversion. Energy 2022, 240, 122509. [CrossRef]

58. Ma, Y.; Liu, C.; E, J.; Mao, X.; Yu, Z. Research on modeling and parameter sensitivity of flow and heat transfer process in typical rectangular microchannels: From a data-driven perspective. Int. J. Therm. Sci. 2022, 172, 107356. [CrossRef]

59. Yi, F.; E, J.; Zhang, B.; Zuo, H.; Wei, K.; Chen, J.; Zhu, H.; Zhu, H.; Deng, Y. Effects of coupling phase change material and liquid cooling on heat dissipation characteristics of Lithium-ion battery thermal management system. Renewable Energy 2022, 181, 472-489. [CrossRef]

60. Cai, T.; Sun, Y.; Zhao, D. Enhancing heat transfer performance analyses of a hydrogen-fueled meso-combustor with staggered bluff-bodies. Fuel Process. Technol. 2021, 218, 106867. [CrossRef]

61. Cai, T.; Zhao, D. Mitigating NOx emissions from an ammonia-fueled micro-power system with a perforated plate implemented. J. Hazard. Mater. 2021, 401, 123848. [CrossRef] [PubMed]

62. Cai, T.; Zhao, D.; Wang, B.; Li, J.W.; Guan, Y.H. NOx emission and thermal performances studies on premixed ammonia-oxygen combustion in a $\mathrm{CO}_{2}$-free micro-planar combustor. Fuel 2020, 280, 118554. [CrossRef]

63. E, J.; Pham, M.; Zhao, D.; Deng, Y.; Le, D.; Zuo, W.; Zhu, H.; Liu, T.; Peng, Q.; Zhang, Z. Effect of different technologies on combustion and emissions of the diesel engine fueled with biodiesel: A review. Renew. Sustain. Energy Rev. 2017, 80, 620-647. [CrossRef]

64. Zhang, B.; Zuo, H.; Huang, Z.; Tan, J.; Zuo, Q. Endpoint forecast of different diesel-biodiesel soot filtration process in diesel particulate filters considering ash deposition. Fuel 2020, 272, 117678. [CrossRef]

65. E, J.; Zhao, M.; Zuo, Q.; Zhang, B.; Zhang, Z.; Peng, Q.; Han, D.; Zhao, X.; Deng, Y. Effects analysis on diesel soot continuous regeneration performance of a rotary microwave-assisted regeneration diesel particulate filter. Fuel 2020, 260, 116353. [CrossRef]

66. Feng, C.; Deng, Y.; Chen, L.; Han, W.; E, J.; Wei, K.; Han, D.; Zhang, B. Hydrocarbon emission control of a hydrocarbon adsorber and converter under cold start of the gasoline engine. Energy 2022, 239, 122138. [CrossRef]

67. Chen, L.; Deng, Y.; Feng, C.; Han, W.; E, J.; Wang, C.; Han, D.; Zhang, B. Effects of zeolite molecular sieve on the hydrocarbon adsorbent performance of gasoline engine of during cold start. Fuel 2022, 310, 122427. [CrossRef]

68. E, J.; Luo, J.; Han, D.; Tan, Y.; Feng, C.; Deng, Y. Effects of different catalysts on light-off temperature of volatile organic components in the rotary diesel particulate filter during the regeneration. Fuel 2022, 310, 122451. [CrossRef]

69. Cai, T.; Zhao, D.; Sun, Y.; Ni, S.; Li, W. Evaluation of NOx Emissions Characteristics in a $\mathrm{CO}_{2}$-Free Micro-Power System by Implementing a Perforated Plate. Renew. Sustain. Energy Rev. 2021, 145, 111150. [CrossRef] 